\title{
Aleksandra Moroska, Prawicowy populizm a eurosceptycyzm (na przykładzie Listy Pima Fortuyna w Holandii i Ligi Polskich Rodzin w Polsce), Wydawnictwo Uniwersytetu Wrocławskiego, Wrocław 2010, ss. 407
}

Aleksandra Moroska znana jest w środowisku politologów i socjologów polityki z zaangażowania w takie zagadnienia naukowe jak populizm, ekstremizm, eurosceptycyzm. Ukazują się również jej publikacje naukowe, które dotyczą przede wszystkim polityki i ustroju Republiki Federalnej Niemiec. Jej książka Prawicowy populizm a eurosceptycyzm (na przykładzie Listy Pima Fortuyna w Holandii i Ligi Polskich Rodzin w Polsce) to obroniona na Uniwersytecie Wrocławskim praca doktorska, napisana pod kierunkiem prof. nadzw. dr. hab. Klausa Bachmanna w Instytucie Politologii Uniwersytetu Wrocławskiego, która w 2011 roku została wyróżniona w drugiej edycji konkursu pod patronatem prezydenta Bronisława Komorowskiego Polskie wyzwania: państwo - tożsamość - rozwój. Autorka otrzymała wyróżnienie w kategorii tematycznej „Tożsamość i kultura”. W niniejszym konkursie wybierani byli autorzy najlepszych prac doktorskich w dziedzinie nauk społecznych.

Autorka postawiła sobie bardzo ambitne zadanie naukowe, które polegało na:

ukazaniu wzajemnych relacji pomiędzy zjawiskami prawicowego populizmu i eurosceptycyzmu, zarówno na płaszczyźnie ideologiczno-programowej, jak i w kontekście rywalizacji wyborczej. W monografii zostały postawione pytania badawcze: Jakie czynniki sprzyjały powstaniu i rozwojowi prawicowego populizmu oraz eurosceptycyzmu w Polsce i Holandii? Jaka była specyfika oblicza ideologiczno-programowego badanych partii? Czym charakteryzo-

1 Marcin Płoski, Absolwent Studium Doktoranckiego Nauk o Polityce, Filozofii i Socjologii, Uniwersytet Wrocławski, Polska, marcin.ploski@wp.pl. 
wały się ich postawy eurosceptyczne i jakie czynniki je warunkowały? Jakie znaczenie odgrywała w mobilizacji wyborców poszczególnych partii kwestia europejska oraz jakie były tego uwarunkowania na poziomie makro i mikro? Jaki był wpływ specyficznych czynników narodowych i zewnętrznych na omawiane zjawiska? (Moroska, 2010, s. 14).

\section{Tym samym:}

w pracy wysunięto dwie hipotezy. Pierwsza zakładała, że charakterystyczne dla partii prawicowo-populistycznych pryncypia ideologiczno-programowe - których rdzeniem jest wertykalna i horyzontalna ekskluzja, a także protekcjonizm w obszarze kulturowym, dążenie do stworzenia silnego i suwerennego państwa, ochrony interesu narodowego w obszarze gospodarczym oraz wzmocnienia wpływu obywateli na władzę - implikują eurosceptyczne postawy Listy Pima Fortuyna i Ligi Polskich Rodzin. Druga - że eurosceptycyzm badanych partii prawicowo-populistycznych przyczynił się do ich sukcesów wyborczych, czyli że w wypadku Listy Pima Fortuyna i Ligi Polskich Rodzin występuje tzw. EU issue voting (Moroska, 2010, s. 14-15).

Dobór analizowanych przypadków oparty został na „tzw. metodzie zgody, autorstwa Milla, lub inaczej podejściu «najbardziej różne systemy» Przeworskiego i Teune’a. Przyjmują one zasadę, że dwa przypadki powinny się różnić pod wszystkimi względami z wyjątkiem analizowanych zmiennych” (Moroska, 2010, s. 15).

Z postawionych zadań badawczych Autorka wywiązała się w pełni, a ponadto jej praca ma prawidłową strukturę (zarówno w podziale na części, rozdziały i podrozdziały). Jej argumentacja układa się w logiczny ciąg zdarzeń. Autorka pisze, że:

monografię oparto także na analizie licznych dokumentów oraz materiałów promocyjnych partii (programy polityczne, programy wyborcze, inne programy okolicznościowe, stanowiska formułowane przez statutowe władze partii, a także ulotki, plakaty, reklamy audiowizualne - spoty wyborcze). Badania uzupełnione zostały analizą takich dzienników, jak: „Gazeta Wyborcza”, „Rzeczpospolita”, „NRC Handelsblad”, „De Volkskrant”, a także partyjnych organów prasowych oraz debat przedwyborczych prezentowanych w telewizji publicznej (Moroska, 2010, s. 18).

O ile się orientuję, dobór materiałów prasowych w przypadku badań nad Listą Pima Fortuyna jest prawidłowy, o tyle w przypadku Ligi Polskich Rodzin jest on 
w znacznej mierze chybiony. Nie wdając się w nadmierne „psychologizowanie”, co kierowało Autorką przy doborze materiałów prasowych, można dojść do wniosku, że posłużyła się ona przy ich wyborze symetrią. Wybrała przede wszystkim jedne z najbardziej poczytnych gazet w Holandii i Polsce. W mojej ocenie ten zabieg powiódł się częściowo, ponieważ w odróżnieniu od Listy Pima Fortuyna, główny dyskurs polityczny dotyczący Ligi Polskich Rodzin miał miejsce przede wszystkim w prasie prawicowej i narodowej, np. w: „Myśli Polskiej”, „Naszej Polsce”, „Naszym Dzienniku”, „Opoce w Kraju”, „Biuletynie Informacyjnym Stronnictwa Narodowego”. O ile wybór „Rzeczpospolitej”, która w przypadku Ligi Polskich Rodzin odznaczała się zasadniczo neutralnością - był trafny, o tyle wybór Gazety Wyborczej, przecież niemal zawsze krytycznej i nieobiektywnej w przypadku analizy zagadnień związanych z Ligą Polskich Rodzin - wydaje się nietrafiony. Konsekwencją wyboru materiałów prasowych w odniesieniu do Ligi Polskich Rodzin są liczne braki merytoryczne w poszczególnych podrozdziałach dotyczących tej partii, jednak o nich napiszę w dalszym toku recenzji.

Książka Autorki cechuje się formalną elegancją, jednak z jednym zastrzeżeniem, które dotyczy sposobu cytowania fragmentów innych autorów. Aleksandra Moroska stosuje tzw. numerowane przypisy dolne, jednakże w żaden sposób ich nie oznacza. Wydaje się to tym bardziej zastanawiające, ponieważ Wydawnictwo Uniwersytetu Wrocławskiego, w którym swoją monografię opublikowała, jest znane z bardzo rygorystycznego przestrzegania praw autorskich. Nakazuje ono autorom publikacji wyodrębnienie z tekstu głównego cytowanych partii tekstu oraz zapis ich najczęściej mniejszą czcionką niż tekst główny albo oznaczenie początku i końca cytowanego tekstu za pomocą znaku cudzysłowu. W przypadku Autorki - z niezrozumiałych dla mnie przyczyn - z tego wymogu zrezygnowano. Ma to swoje konsekwencje, które polegają na tym, że czytając tekst książki, nie wiadomo, co jest myślą, poglądem, refleksją nad problemem naukowym Autorki, a co jest własnością intelektualną innych autorów. W efekcie poglądy Autorki i innych autorów najczęściej zlewają się w jedną całość, potęgując uczucie chaosu. Nie ma sensu przytaczać konkretnych fragmentów tekstu, ponieważ jest ich tak wiele, że na ich przytoczenie nie pozwalają ramy objętościowe standardowej recenzji. Zdarzają się przypadki, iż niemal na każdej stronie książki mamy pomieszanie poglądów Autorki i innych autorów. W zasadzie tylko intuicja czytelnika, która może być zawodna, pozwala na oddzielenie fragmentów należących do Autorki od innych autorów. Analiza książki przez to jest zajęciem żmudnym i karkołomnym - przynajmniej w aspekcie wkładu Autorki do analizowanego zagadnienia naukowego.

Nieodpowiedni dobór materiałów prasowych, moim zdaniem, wpłynął negatywnie na zawartość merytoryczną podrozdziału 8.5 Geneza Ligi Polskich 
Rodzin. Samo zagadnienie dla środowiska Ligi Polskich Rodzin stanowiło temat drażliwy, a jej przywódcy wypowiadali się w tej kwestii niechętnie. Jednakże dość obszernie o tym procesie rozpisywała się prasa narodowa. Powstanie Ligi Polskich Rodzin poprzedził proces zjednoczeniowy środowisk narodowych uosobiony w dwóch partiach politycznych bez większego znaczenia politycznego, a mianowicie Stronnictwa Narodowego i Stronnictwa-Narodowo-Demokratycznego. Proces zjednoczeniowy rozpoczął się 19 kwietnia 1999 roku w momencie, gdy prezes Stronnictwa Narodowo-Demokratycznego, Bogusław Kowalski zwraca się do prezesa Zarządu Głównego Stronnictwa Narodowego Andrzeja Horodeckiego z propozycją nawiązania współpracy z pozostałymi środowiskami narodowymi. Kolejny etap procesu zjednoczeniowego nastąpił w 2002 roku. Polegał on na rozwiązaniu partii politycznej - Stronnictwo Narodowe, a następnie powołaniu stowarzyszenia o tej samej nazwie. Zasadniczym celem zmiany formuły prawnej Stronnictwa Narodowego był zamiar stworzenia w miejsce dotychczasowej partii politycznej Stronnictwo Narodowe nowej partii, czyli Ligi Polskich Rodzin.

Druga faza procesu zjednoczeniowego to utworzenie w 2001 roku jednej partii politycznej pod nazwą Liga Polskich Rodzin, która tak naprawdę składała się z konglomeratu wielu partii i organizacji społecznych, które funkcjonowały poza głównym nurtem politycznym III Rzeczpospolitej Polskiej. Celem tego zabiegu było ominięcie ośmioprocentowego progu wyborczego dla koalicji wyborczych. Autorka enumeratywnie wymienia takie ugrupowania jak: Liga Rodzin, Stronnictwo Narodowe, Stowarzyszenie Polskiej Racji Stanu, Ruch Katolicko-Narodowy Antoniego Macierewicza, Porozumienie Polskie Jana Łopuszańskiego, Klub „Myśl dla Polski”, Liga Polska, Młodzież Wszechpolska oraz Porozumienie dla Polski Gabriela Janowskiego, Ruch Odbudowy Polski Jana Olszewskiego (por. Moroska, 2010, s. 227-228). Taka lakoniczna informacja nie mówi nic o kwestiach programowych ugrupowań politycznych tworzących Ligę Polskich Rodzin.

Uważny obserwator polskiej sceny politycznej dostrzegłby, że głównym kanałem komunikacji z wyborcami, zwłaszcza na etapie powstawania Ligi Polskich Rodzin, jak i obecnie, pozostawał Internet, toteż oficjalne materiały programowe poszczególnych ugrupowań tworzących Ligę znajdowały się na ich stronach internetowych. Autorka jednak nie sięgnęła do tych informacji. Z tego powodu z książki Aleksandry Moroskiej dowiadujemy się, że głównym powodem występowania animozji w Lidze były spory ambicjonalne charyzmatycznych polityków tworzących partię. Jest to półprawda, ponieważ jedną z istotnych przyczyn występowania tendencji odśrodkowych w tej partii politycznej był fakt, że formalnie było to jedno ugrupowanie politycznie, a nieoficjalnie składało się 
z wielu podmiotów o sprzecznych założeniach programowych. Przykładem może być Porozumienie Polskie, które opowiadało się i głosowało jeszcze w okresie, gdy było częścią Akcji Wyborczej „Solidarność” przeciwko ratyfikacji Traktatu Waszyngtońskiego, uznając, że przystępując do Paktu Północnoatlantyckiego Polska znajdzie się wśród państw militarnie i gospodarczo silniejszych. Z kolei Ruch Katolicko-Narodowy Antoniego Macierewicza i Ruch Odbudowy Polski Jana Olszewskiego wspólnie opowiadały się za podjęciem przez rząd Polski działań na rzecz odzyskania należnych Polsce reparacji wojennych od Niemiec. Natomiast program Stowarzyszeń Uwłaszczeniowych i Gospodarczych Adama Bieli zawierał projekt ustawy uwłaszczeniowej, który jednakże nie został zrealizowany ze względu na jej radykalizm - koszty uwłaszczenia niosłyby za sobą ogromne obciążenia dla budżetu państwa.

Aleksandra Moroska w swojej książce posłużyła się nie w pełni miarodajnym źródłem w aspekcie ilości polityków, którzy dostali się z ugrupowań tworzących Ligę Polskich Rodzin do parlamentu. W tym celu przytoczyła dane przedstawione przez Mateusza Piskorskiego (przypis 718) (Piskorski, 2004, s. 173). Autor ten nie podaje np. jednego ugrupowania, a mianowicie Stowarzyszeń Uwłaszczeniowych i Gospodarczych Adama Bieli, z którego co prawda dostała się jedna osoba do Sejmu. Jednakże było ono istotne ze względów polityczno-programowych. Lepsze byłoby posłużenie się danymi, które opublikował Maciej Giertych w „Opoce w Kraju” (Giertych, 2001, s. 1).

Zaskakujące było ujęcie zagadnienia współpracy Radia Maryja i Ligi Polskich Rodzin, któremu Autorka poświęca zaledwie kilka zdań. Każda partia polityczna organizacyjnie i ideologicznie zbudowana jest według tego samego schematu. Składają się na nią: myśl polityczno-programowa, więzi z tradycyjnymi środowiskami społecznymi, które są zapleczem społecznym partii (w przypadku LPR byli to słuchacze Radia Maryja), wiarygodni liderzy, obraz partii w mass mediach, własna baza medialna i prasowo-wydawnicza (czas antenowy w Radiu Maryja, czasopisma „Racja Polska”, „Polityka Narodowa”, „Aspekt Polski”), baza członkowska (Żebrowski, 2003, s. 194; Płoski, 2016a, s. 51).

Autorka w sposób niewystarczający poświęciła uwagę sojuszniczemu wsparciu medialnemu Radia Maryja dla Ligi Polskich Rodzin. Część socjologów, m.in. Janusz Czapiński, Jadwiga Staniszkis byli zdania, że dyrektor Radia Maryja o. Tadeusz Rydzyk jest w stanie przesuwać poparcie elektoratu prawicowego do namaszczonej przez siebie partii politycznej. Według nich o. Tadeusz Rydzyk za pośrednictwem Radia Maryja jest w stanie przysporzyć kilkuprocentowe poparcie polityczne ze strony elektoratu radiomaryjnego. Podkreśla się również ogromny potencjał mobilizacyjny tego elektoratu tuż przed wyborami. 
Autorka nie posłużyła się badaniami socjologicznymi, choćby Centrum Badania Opinii Społecznej, aby ukazać fenomen wzajemnego przenikania się środowiska Radia Maryja i Ligi Polskich Rodzin. „Zdecydowana większość członków Ligi Polskich Rodzin była słuchaczami Radia Maryja (61\%). Spośród organizacji związanych ideologicznie lub organizacyjnie 25\% członków Ligi Polskich Rodzin należało do Kół Przyjaciół Radia Maryja” (Płoski, 2016b, s. 151).

Aleksandra Moroska słusznie zauważa, że dla Ligi Polskich Rodzin podstawową wartością był naród (por. Moroska, 2010, s. 255). Jednakże sama Autorka powinna dostrzec, że w środowisku narodowym termin „naród” ma inne znaczenie niż potocznie stosowane, co powinno zostać zasygnalizowane choćby w formie przypisu. Dla członków i przywódców Ligi Polskich Rodzin „naród polski” to etniczni Polacy. Stanowisko to nie uległo zmianie nawet po późniejszym wyroku Trybunału Konstytucyjnego z 2008 roku, który orzekł, że pojęcie „naród” należy łączyć z posiadaniem obywatelstwa polskiego, a nie z przynależnością do narodu polskiego.

Na szczególną uwagę zasługuje Rozdział 12 Lista Pima Fortuyna i Liga Polskich Rodzin jako partie prawicowo-populistyczne i eurosceptyczne. Podobieństwa i różnice. Napisanie tego rozdziału wymagało wysokiej sprawności intelektualnej oraz bardzo pogłębionej wiedzy z zakresu różnych dyscyplin naukowych, m.in. historii (historii Holandii i Polski), politologii, socjologii (szczególnie struktur społecznych). Autorka w sposób rzeczowy przedstawia różnice pomiędzy poszczególnymi krajami. Jej analizy cechowała bezstronność i sprawiedliwość osądu. Wysuwa ona zasadny wniosek, „iż pomimo odmiennych uwarunkowań wewnątrzpolitycznych i doświadczeń związanych z integracją europejską - w obu wypadkach zaistniały podobne procesy i mechanizmy sprzyjające powstaniu i rozwojowi eurosceptycznych partii populistyczno-prawicowych” (Moroska, 2010, s. 329).

Zarówno w przypadku Ligi Polskich Rodzin, jak i Listy Pima Fortuyna mieliśmy do czynienia z procesem określanym jako „żelazne prawo oligarchii”, owe prawo zostało stworzone przez Roberta Michelsa w 1911 roku. Obie partie były zarządzane przez charyzmatycznych przywódców, tj. przez Pima Fortuyna i Romana Giertycha - wybranego w 2006 roku na prezesa Ligi Polskich Rodzin. Najpierw pełnią oni swoje funkcje honorowo i bezpłatnie, a następnie stają się zawodowymi przywódcami, tworząc stabilne i nienaruszalne kierownictwo, jednocześnie uwalniając się od mas (por. Michels, 1995, s. 147-148). Obie partie polityczne były efemerydami politycznymi, a więc zjawiskami politycznymi krótkotrwałymi, zanikającymi. Nie oznacza to jednak, że poglądy eurosceptyczne są w zaniku, 
ponieważ powstają nowe partie eurosceptyczne, w innych z kolei powstają frakcje eurosceptyczne. Realnym zwycięstwem eurosceptycyzmu był niewątpliwie Brexit.

Aleksandra Moroska wykonała ogromną pracę, przygotowując się do napisania recenzowanej książki. W sposób obszerny opisała dwie eurosceptyczne partie polityczne w jednej książce, co nie zdarza się zbyt często. Uchylam się od odpowiedzi na pytanie, jak znaczący jest wkład Autorki w opisywany przez nią temat, ze względu na podnoszoną przeze mnie kwestię cytowania innych autorów. Gdyby tytuł książki brzmiał: Prawicowy populizm a eurosceptycyzm na przykładzie Listy Pima Fortuyna w Holandii należałoby ją ocenić jako ponadprzeciętną, jednak ze względu na mankamenty występujące w części poświęconej Lidze Polskich Rodzin tę ocenę, w moim przekonaniu, należy obniżyć.

\section{Bibliografia:}

Giertych, M. (2001). Liga Polskich Rodzin w Sejmie. Opoka w Kraju, 40 (61). Pobrane z: http://opoka.giertych.pl/owk40.htm.

Michels, R. (1995). Oligarchiczne tendencje organizacji. W: J. Szczupaczyński (wyb. i opr.), Władza i społeczeństwo. Antologia tekstów z zakresu socjologii polityki (s. 147-148). Warszawa: Wydawnictwo „Scholar”.

Moroska, A. (2010). Prawicowy populizm a eurosceptycyzm (na przykładzie Listy Pima Fortuyna w Holandii i Ligi Polskich Rodzin w Polsce). Wrocław: Wydawnictwo Uniwersytetu Wrocławskiego.

Piskorski, M. (2004). Liga Polskich Rodzin. W: K. Kowalczyk, J. Sielski (red.), Polskie partie i ugrupowania parlamentarne (s. 169-173). Toruń: Wydawnictwo Adam Marszałek.

Płoski, M. (2016a). Socjologiczny portret upadku aktora politycznego na przykładzie Ligi Polskich Rodzin. Przegląd Politologiczny, 1, s. 49-61. DOI: 10.14746/pp.2016.21.1.4.

Płoski, M. (2016b). Liga Polskich Rodzin jako aktor społeczny. Pobrane z: http://www. repozytorium.uni.wroc.pl/publication/80114.

Żebrowski, W. (2003). Stronnictwo Demokratyczne w warunkach demokratyzacji ustroju politycznego. Olsztyn: Olsztyńska Szkoła Wyższa. 